\title{
Pemurnian dan Karakterisasi Silika Menggunakan Metode Purifikasi (Leaching) dengan Variasi Waktu Milling pada Pasir Kuarsa Desa Pasir Putih Kecamatan Pamona Selatan Kabupaten Poso
}

\author{
Purification and Characterization of Silica Using Purification \\ (Leaching) Method with Variations of Milling Time from Quartz Sand \\ on Pasir Putih Village South Pamona Sub-district of Poso District
}

\author{
Darmawati Darwis*), Rany Khaeroni, dan Iqbal \\ Jurusan Fisika, Fakultas MIPA Universitas Tadulako \\ Jln. Soekarno Hatta Km. 9 Bumi Kaktus, Tadulako, Palu
}

\begin{abstract}
The research on purification and characterization of silica from quartz sand on Pasir Putih village South Pamona sub-district of Poso has been carried out. This research aims to obtain high-purity silica $\left(\mathrm{SiO}_{2}\right)$ using purification (leaching) method with various milling times for 2-5 hours. Before purification, the quartz sand has been mashed using milling ball. Then soaked it in $2 \mathrm{M} \mathrm{HCl}$ for 12 hours and rinsed with aquades to $\mathrm{pH}$ neutral. Afterwards, each sample was characterized using XRF and XRD. Results of XRF analysis show that the highest purity of silica obtained from the 5 hour-milled sample is $99,90 \%$. Results of XRD analysis on the sample matched with software Search Match and JCPDS data indicate that the hexagonal systems of the crystal's structure of silica including the diffraction plane spacing, lattice constant, and the degree of crystalline are $3,35 \AA \hat{A}, \mathrm{a}=\mathrm{b}=\mathrm{d}=4,90 \AA \hat{\mathrm{A}}, \mathrm{c}=5,44$ $\AA$, dan $80,11 \%$ respectively.
\end{abstract}

Keywords: Purification (leaching) method, silica, and crystal's structure

\begin{abstract}
ABSTRAK
Penelitian tentang pemurnian dan karakterisasi silika pada pasir kuarsa Desa Pasir Putih Kecamatan Pamona Selatan Kabupaten Poso telah dilakukan. Penelitian ini bertujuan untuk memperoleh kadar kemurnian silika $\left(\mathrm{SiO}_{2}\right)$ yang tinggi menggunakan metode purifikasi (leaching) dengan variasi waktu milling selama 2-5 jam. Sebelum pemurnian, pasir kuarsa dihaluskan dengan menggunakan ball milling. Selanjutnya direndam dalam larutan $\mathrm{HCl} 2 \mathrm{M}$ selama 12 jam lalu dibersihkan dengan aquades hingga $\mathrm{pH}$ netral. Sesudah itu, setiap sampel dikarakterisasi menggunakan alat XRF dan XRD. Dari hasil karakterisasi XRF diperoleh kadar kemurnian silika tertinggi terdapat pada sampel dengan waktu milling 5 jam $(99,90 \%)$. Kemudian hasil karakterisasi XRD pada sampel tersebut memiliki struktur kristal dengan sistem kristal hexagonal, yang meliputi jarak bidang difraksi, konstanta kisi, dan derajat kristalin ketika dicocokkan dengan software Search Match dan data JCPDS ialah

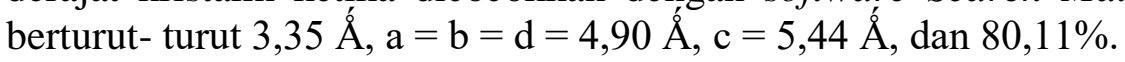

Kata Kunci: Metode purifikasi (leaching), silika, dan struktur kristal 


\section{LATAR BELAKANG}

Salah satu energi terbarukan yang memiliki potensi untuk dapat menggantikan energi fosil adalah energi surya yang sumber energinya memanfaatkan radiasi matahari. Energi radiasi matahari ini dapat diubah menjadi arus listrik dengan menggunakan panel surya yang bahan bakunya terbuat dari bahan semikonduktor (Halme, 2002). Bahan semikonduktor yang banyak digunakan dan mudah diperoleh saat ini ialah silikon. Namun, silikon sangat jarang ditemukan unsur bebasnya (silikon murni), hanya dalam bentuk senyawa silika $\left(\mathrm{SiO}_{2}\right)$, sehingga untuk menghasilkan silikon yang murni, maka diperlukan kemurnian silika yang tinggi pula. Silika yang dimanfaatkan untuk bahan baku pembuatan panel surya harus mempunyai kemurnian sebesar 99,99\% (Stanitski, 2003).

Metode pemurnian yang dilakukan untuk mendapatkan silika yang murni yaitu metode purifikasi (leaching) (Suparsih, 2013). Metode purifikasi (leaching) merupakan metode sintesis dengan menggunakan prinsip transfer difusi komponen terlarut dari padatan inert ke dalam pelarutnya sehingga dapat mengurangi kandungan unsur-unsur pengotor dalam pasir kuarsa. Menurut Adjiantoro et al., (2016), pelarut yang dapat digunakan untuk menghasilkan kadar kemurnian silika $\left(\mathrm{SiO}_{2}\right)$ yang tinggi ialah larutan $\mathrm{HCl}$.

Pasir kuarsa dapat dengan mudah untuk disintesis atau dimurnikan dalam larutan $\mathrm{HCl}$ apabila ukuran partikel pasir kuarsa berukuran nano atau serbuk (Pramudono et al., 2008). Alat yang digunakan untuk mereduksi ukuran partikel silika menjadi serbuk ialah alat ball milling. Alat ini dapat mereduksi ukuran partikel dengan menggunakan bola- bola besi yang berputar pada suatu wadah untuk memberikan beban dinamis agar menjadi serbuk (Xiao et al., 2007).

Penelitian sebelumnya telah dilakukan oleh Indah Ukhtiyani (2017) yaitu mengenai pemurnian silika dari pasir kuarsa di Desa Pasir Putih Kecamatan Pamona Selatan Kabupaten Poso dengan menggunakan metode purifikasi (leaching) dan milling selama 1 jam menggunakan alat ball milling dan diperoleh kadar silika sebesar $99,88 \%$. Hasil pemurnian tersebut belum memenuhi syarat pemurnian yang dibutuhkan untuk bahan baku pembuatan panel surya. Oleh karena itu, perlu dilakukan penelitian untuk mengoptimasikan pemurnian dari senyawa silika $\left(\mathrm{SiO}_{2}\right)$ dalam pasir kuarsa Desa Pasir Putih Kecamatan Pamona Selatan Kabupaten Poso menggunakan metode purifikasi (leaching) dengan variasi waktu milling dan mengetahui struktur kristal 
dari setiap pasir kuarsa yang telah di milling.

\section{BAHAN DAN METODE}

Bahan yang digunakan pada penelitian ini yaitu pasir kuarsa yang berasal dari Desa Pasir Putih Kecamatan Pamona Selatan Kabupaten Poso. Pasir dicuci menggunakan air PDAM hingga bersih dan dikeringkan pada suhu udara normal serta diayak menggunakan ayakan 60 Mesh. Selanjutnya melakukan pemisahan pasir besi menggunakan sebuah magnet.

Setelah pemisahan besi, pasir digiling menggunakan alat milling ball yang akan merubah bentuk pasir menjadi serbuk. Alat yang digunakan dalam proses milling yaitu ball milling KT-6808 MINITUMBLER yang telah dimodifikasi. Proses milling dilakukan dengan 4 waktu berbeda, yaitu 2 jam, 3 jam, 4 jam, dan 5 jam.

Setalah proses milling, setiap pasir kuarsa direndam menggunakan larutan $\mathrm{HCl} 2 \mathrm{M}$ sebanyak $50 \mathrm{ml}$ selama 12 jam. Kemudian dicuci menggunakan aquades hingga $\mathrm{PH}$ sampel kembali netral (PH 7) dan dikeringkan pada suhu udara normal hingga kadar air hilang. Hasil pemurnian berupa silika berwarna putih dan selanjutnya akan dikarakterisasi menggunakan alat XRF dan XRD.

\section{HASIL DAN PEMBAHASAN Pemurnian Pasir Kuarsa}

Pemurnian yang dilakukan pada setiap sampel pasir kuarsa yang telah digiling pada variasi waktu yang berbeda menghasilkan perubahan warna pada setiap sampel yang awalnya abu-abu menjadi putih. Perubahan warna ini terjadi akibat terlarutnya senyawa pengotor yang terdapat dalam setiap sampel pasir kuarsa ke pelarutnya. Senyawa pengotor yang terlarut akan membentuk koloid dan kemudian koloid tersebut dibuang bersamaan dengan larutan $\mathrm{HCl}$ yang merendam pasir kuarsa (Ukhtiyani, 2017).

\section{Hasil XRF (X-Ray Fluorescence)}

Hasil XRF diperoleh bahwa persentase senyawa $\mathrm{SiO}_{2}$ setelah pemurnian lebih tinggi dari sebelum dilakukan pemurnian, hal ini memperlihatkan bahwa metode purifikasi dengan variasi waktu milling dapat meningkatkan kemurnian silika $\left(\mathrm{SiO}_{2}\right)$, seperti yang dapat dilihat pada Tabel 1 .

Konsentrasi silika tertinggi terdapat pada sampel yang digiling selama 5 jam. Hal ini dikarenakan Pada saat proses milling, pasir kuarsa yang terdapat dalam alat ball milling akan menjadi halus akibat bolabola besi yang berputar secara sentrifugal dan saling bertumbukan di dalam dinding tabung ball milling, sehingga semakin lama waktu milling maka semakin halus 
atau kecil ukuran partikel pasir kuarsa (Li et al., 2005).

Tabel 1 Hasil XRF (X-Ray Flourescence) Pasten Kuarsa

\begin{tabular}{|c|c|c|c|c|}
\hline $\begin{array}{c}\text { Nama } \\
\text { Senyawa }\end{array}$ & $\begin{array}{c}\text { Presentase } \\
\text { Berat } \\
\text { Senyawa } \\
\text { Sampel 1 } \\
(\%)\end{array}$ & $\begin{array}{c}\text { Presentase } \\
\text { Berat } \\
\text { Senyawa } \\
\text { Sampel 2 } \\
(\%)\end{array}$ & $\begin{array}{c}\text { Presentase } \\
\text { Berat } \\
\text { Senyawa } \\
\text { Sampel 3 } \\
(\%)\end{array}$ & $\begin{array}{c}\text { Presentase } \\
\text { Berat } \\
\text { Senyawa } \\
\text { Sampel 4 } \\
(\%)\end{array}$ \\
\hline $\mathrm{SiO}_{2}$ & 99,51 & 99,89 & 99,89 & 99,90 \\
\hline $\mathrm{TiO}_{2}$ & 0,0726 & 0,0551 & 0,0625 & 0,0360 \\
\hline $\mathrm{Cr}_{2} \mathrm{O}_{3}$ & 0,0219 & - & - & 0,0110 \\
\hline $\mathrm{Nb}_{2} \mathrm{O}_{5}$ & 0,0141 & 0,0184 & 0,0152 & 0,0163 \\
\hline $\mathrm{MoO}_{3}$ & 0,0107 & 0,0136 & 0,0115 & 0,0131 \\
\hline $\mathrm{ZrO}_{2}$ & 0,0073 & - & - & - \\
\hline $\mathrm{P}_{2} \mathrm{O}_{5}$ & 0,224 & - & - & - \\
\hline $\mathrm{Fe}_{2} \mathrm{O}_{3}$ & 0,0983 & - & - & - \\
\hline $\mathrm{CaO}_{2}$ & 0,0192 & - & - & - \\
\hline $\mathrm{In}_{2} \mathrm{O}_{3}$ & - & 0,0055 & 0,0053 & 0,0056 \\
\hline
\end{tabular}

Ket: Sampel 1 = Sebelum milling dan pemurnian

Sampel 2 = Sesudah pemurnian dan waktu milling 2 jam

Sampel 3 = Sesudah pemurnian dan waktu milling 3 janTabel 2 Hasil pencocokkan data XRD

Sampel 4 = Sesudah pemurnian dan waktu milling 5 jam

(Sumber: Hasil Penelitian Dengan Menggunakan Alat Karakterisasi XRF Laboratorium Terpadu Universitas Hasanudin)

\section{Hasil XRD (X-Ray Diffration)}

Hasil karakterisasi XRD pada setiap sampel berupa intensitas difraksi sinar-X yang terdifraksi dan sudut-sudut (20) yang terbentuk berkisar antara $21^{\circ}$ dan $69^{\circ}$ sehingga menyebabkan terjadinya variasi d-value (Á). Hasil XRD dianalisis dengan software Search Match untuk melihat kesesuaian struktur kristal yang meliputi sistem kristal, konstanta kisi dan bidang difraksi $\left(\mathrm{d}_{\mathrm{hkl}}\right)$.

Data yang diperoleh dari hasil XRD dengan software Search Match mengalami pergeseran nilai sudut difraksi dan jarak bidang difraksi pada intensitas tertinggi yang dapat dilihat pada Tabel 2. Namun nilai sudut dan bidang difraksi $\left(\mathrm{d}_{\mathrm{hkl}}\right)$ dari kedua data ini tidak terlalu berbeda jauh dengan nilai bidang difraksi silika pada fase kuarsa (quartz). Menurut Flörke et al. (1986), fase kuarsa dapat ditunjukkan pada

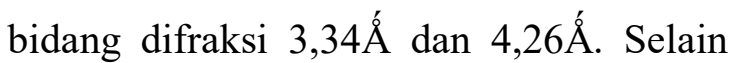
itu, menurut Munasir (2013) posisi sudut yang menghasilkan intensitas maksimum dan teridentifikasi sebagai fase kuarsa ialah pada posisi $2 \theta=26,61^{\circ}$. Dengan demikian dapat dinyatakan bahwa sampel tersebut mengidentifikasi fase kuarsa.

\begin{tabular}{|c|c|c|c|c|c|c|}
\hline \multirow{2}{*}{ Sampel } & \multicolumn{2}{|c|}{ Hasil XRD } & \multicolumn{2}{|c|}{$\begin{array}{c}\text { Hasil } \\
\text { Perhitungan }\end{array}$} & \multicolumn{2}{|c|}{ Search Match } \\
\hline & $\begin{array}{l}\mathbf{d}_{\text {hkl }} \\
(\AA \AA)\end{array}$ & $2 \theta\left({ }^{\circ}\right)$ & $\begin{array}{l}\mathbf{d}_{\text {hkl }} \\
(\AA ̊)\end{array}$ & $2 \theta\left({ }^{\circ}\right)$ & $\begin{array}{l}\mathbf{d}_{\text {hkl }} \\
(\AA \AA)\end{array}$ & $2 \theta\left({ }^{\circ}\right)$ \\
\hline 1 & $\begin{array}{c}3,2 \\
6\end{array}$ & 27,31 & $\begin{array}{c}3,3 \\
0\end{array}$ & 27,31 & $\begin{array}{c}3,3 \\
3\end{array}$ & 27,29 \\
\hline 2 & $\begin{array}{c}3,3 \\
1\end{array}$ & 26,88 & $\begin{array}{c}3,3 \\
4\end{array}$ & 26,88 & $\begin{array}{c}3,3 \\
3\end{array}$ & 26,97 \\
\hline 3 & $\begin{array}{c}3,2 \\
6\end{array}$ & 27,31 & $\begin{array}{c}3,3 \\
2\end{array}$ & 27,31 & $\begin{array}{c}3,2 \\
6\end{array}$ & 27,33 \\
\hline 4 & $\begin{array}{c}3,3 \\
3\end{array}$ & 26,73 & $\begin{array}{c}3,3 \\
5\end{array}$ & 26,73 & $\begin{array}{c}3,3 \\
5\end{array}$ & 26,66 \\
\hline
\end{tabular}

Ket: Sampel 1 = Sesudah pemurnian dan waktu milling 2 jam Sampel $2=$ Sesudah pemurnian dan waktu milling 3 jam Sampel 3 = Sesudah pemurnian dan waktu milling 4 jam Sampel $4=$ Sesudah pemurnian dan waktu milling 5 jam

Sampel yang mendekati nilai data Flörke et al. dan Munasir yaitu sampel yang digiling selama 5 jam yang nilai bidang difraksi dari data XRD software Search Match dan hasil perhitungan berturut-turut 3,33 Á, 3,34 Á, dan 3,35 Á serta posisi sudut yang dibentuk oleh sampel saat di milling 5 jam ialah $2 \theta=$ 26,66 ${ }^{\circ}$. Hasil pencocokkan data XRD saat 
waktu milling 5 jam dengan software

Search Match dapat dilihat pada Gambar 1.

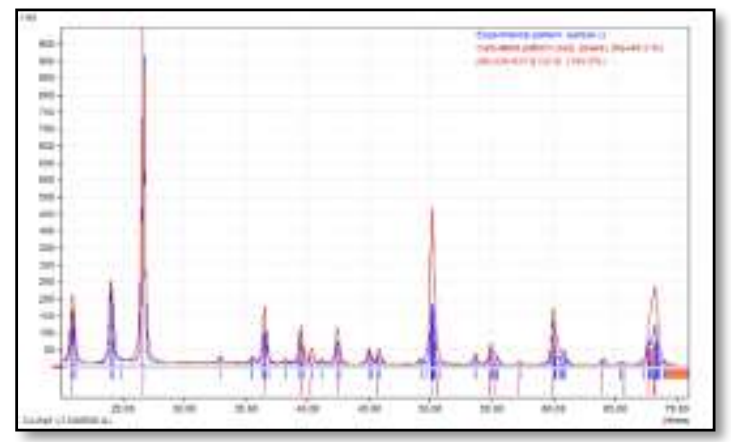

Gambar 1 Grafik hubungan Intensitas terhadap sudut difraksi data sampel serbuk pasir kuarsa setelah pemurniaan $\mathrm{HCl}$ saat waktu milling.

Ket: Garis biru merupakan sampel serbuk, garis merah merupakan data hasil Bank data Search Match.

Hasil pencocokkan data XRD dengan software Search Match dari 4 sampel pasir kuarsa dapat diketahui sistem kristal dari senyawa silika $\left(\mathrm{SiO}_{2}\right)$ yaitu hexagonal axes. Konstanta kisi dalam hexagonal axes setiap sampel dapat diketahui jika diketahui juga indeks Miller pada setiap sudut difraksi. Nilai indeks Miller dari setiap sampel dapat diketahui dengan mencocokkan jarak bidang difraksi hasil XRD dengan data JCPDS (Joint Committee on Powder Diffraction Standards), kemudian menggunakan Persamaan 1, Persamaan 2, dan Persamaan 3 untuk menghitung konstanta kisi.
Persamaan menghitung jarak antar bidang $\left(\mathrm{d}_{\mathrm{hkl}}\right)$ dan konstanta kisi pada kristal heksagonal:

$$
\begin{aligned}
& \frac{1}{d^{2}}=\frac{4}{3}\left(\frac{h^{2}+h k+k^{2}}{a^{2}}\right)+\frac{l^{2}}{c^{2}} \quad 1 \\
& \mathrm{a}=\mathrm{b}=\frac{\lambda}{\sqrt{3} \sin \theta} \sqrt{h^{2}+h k+k^{2}} \quad 2 \\
& \mathrm{c}=\frac{\lambda}{2 \sin \theta} l
\end{aligned}
$$

Dari persamaan tersebut diperoleh nilai konstata kisi XRD saat waktu milling 5 jam hampir sama dengan konstanta kisi pada data JCPDS, yaitu $\mathrm{a}=\mathrm{b}=\mathrm{d}=4,90 \AA$ 囟

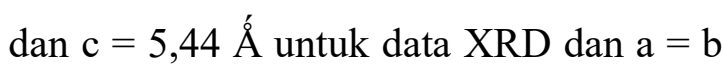
$=\mathrm{d}=4,89 \AA \AA$ dan $\mathrm{c}=5,49 \AA$ Á untuk data JCPDS.

Hasil pencocokkan data XRD dengan software Search Match juga dapat diketahui derajat kristalin dari setiap sampel dengan cara menghilangkan background pada software Search Match. Kemudian, dilakukan perhitungan derajat kristalin yang hasilnya seperti pada Tabel 3.

Tabel 3 Hasil perhitungan derajat kristalin dari tiap sampel

\begin{tabular}{|c|c|c|}
\hline No & Sampel & $\begin{array}{c}\text { Kristalinitas } \\
(\mathbf{\%})\end{array}$ \\
\hline 1. & $\begin{array}{c}\text { Sesudah waktu } \\
\text { milling 2 jam }\end{array}$ & 90,40 \\
\hline 2. & $\begin{array}{c}\text { Sesudah waktu } \\
\text { milling 3 jam }\end{array}$ & 85,58 \\
\hline 3. & Sesudah waktu & 83,11 \\
\hline
\end{tabular}




\begin{tabular}{|c|c|c|}
\hline No & Sampel & $\begin{array}{c}\text { Kristalinitas } \\
(\mathbf{\%})\end{array}$ \\
\hline & milling 4 jam & \\
\hline 4. & $\begin{array}{c}\text { Sesudah waktu } \\
\text { milling 5 jam }\end{array}$ & 80,11 \\
\hline
\end{tabular}

Dari hasil perhitungan tersebut dapat dilihat adanya penurunan derajat kristalinitas sampel sesudah dimurnikan dari waktu milling 2 jam hingga 5 jam. Hal ini disebabkan karena ukuran butir sampel saat waktu milling lebih kecil sehingga ketika sampel direndam dalam larutan $\mathrm{HCl}$, maka larutan tersebut akan lebih mudah berdifusi dan mendegradasi ikatan atom yang ada dalam sampel. Menurut Kittel (1996), susunan partikel dalam zat padat menentukan sifat dari zat padat. Perbedaan susunan partikel dalam berbagai zat padat disebabkan oleh perbedaan gaya ikat di antara atom-atom, ion-ion, atau molekul-molekul penyusunnya.

Berdasarkan hasil dari karakterisasi dengan mengidentifikasi 4 sampel pasir kuarsa dapat disimpulkan bahwa pasir kuarsa yang berasal dari Desa Pasir Putih Kecamatan Pamona Selatan Kabupaten Poso memiliki senyawa silika $\left(\mathrm{SiO}_{2}\right)$ dengan sistem kristal hexagonal axes pada intensitas tertinggi. Hasil XRD dari pasir kuarsa dengan metode pemurnian ini menunjukkan bahwa pasir tersebut berpotensi untuk dapat dijadikan sebagai bahan baku panel surya karena memiliki kemurnian silika sebesar 99,90\%. Selain itu, pemurnian pasir kuarsa menggunakan metode purifikasi (leaching) dengan variasi waktu milling terbukti dapat meningkatkan kadar kemurnian silika.

\section{UCAPAN TERIMA KASIH}

Terima kasih diucapkan kepada laboran jurusan kimia dan fisika FMIPA UNTAD yang telah meminjamkan alatalat penelitian serta kepada Ristek Dikti yang telah membiayai penelitian ini hingga selesai.

\section{DAFTAR PUSTAKA}

Adjiantoro, Bintang, and Efendi Mabruri. (2016). Pengaruh Waktu Pelindian Pada Proses Pemurnian Silikon Tingkat Metalurgi Menggunakan Larutan HCl. Metalurgi, 27(1), 1-6.

Flörke, Ow, and H Schneider. (1986). Verwachsungsbeziehungen Der Sio2-Polymorphe Quarz, Cristobalit Und Tridymit In Sio2Reichen Keramischen Werkstoffen. Paper read at CFI. Ceramic forum international, 63(7-8), 368-372.

Halme, Janne. (2002). Dye-Sensitized Nanostructured and Organic Photovoltaic Cells: Technical Review And Preliminary Tests. Master of Science in Technology, Helsinki University of Technology. Finlandia.

Kittel, C. (1996). Introduction to Solid State Physics. Singapoera: John Willey.

Li, Bin, Jun Xia, Yang Wang, and Bijun Xie. (2005). Structure characterization and its antiobesity 
of ball-milled konjac flour.

European Food Research and Technology, 221(6), 814-820.

Mondadori, A. (1977). Simons \&

Schuster's Guide to Rocks and

Minerals. Milan: Simons \&

Schuster's Inc.

Munasir, Triwikantoro, Moch.Zainuri, Darminto. (2013). Ekstraksi Dan Sintesis Nanosilika Berbasis Pasir Bancar dengan Metode Basah. Jurnal Penelitian Fisika dan Aplikasinya (JPFA), 3(2), 12-17.

Pramudono, Bambang, Septian Ardi Widioko, and Wawan Rustyawan. (2008). Ekstraksi Kontinyu Dengan Simulasi Batch Tiga Tahap Aliran Lawan Arah: Pengambilan Minyak Biji Alpukat Menggunakan Pelarut N-Hexane Dan Iso Propil Alkohol. Reaktor, 12(1), 37-41.

Stanitski, L. (2003). Chemistry in Context. Edited by A. C. t. Society, 4th ed. New York: Mc Graw-Hill.

Suparsih, T. H. S., Zainuri, M. (2013). Sintesis Silika dari Pasir Alam Tuban. Jurnal Teknik POMITS, 1(1), 1-3.

Ukhtiyani, I. (2017). Purifikasi dan Karakterisasi Silika $\left(\mathrm{SiO}_{2}\right)$ Berbasis Pasir Kuarsa dari Desa Pasir Putih Kecamatan Pamona Selatan Kabupaten Poso. Skripsi. Fakultas Matematika dan Ilmu Pengetahuan Alam, Universitas Tadulako. Palu.

Xiao, Xu-xian, Ke-long Huang, and Qiong-Qiong He. (2007). Synthesis and characterization of aminated $\mathrm{SiO}_{2} / \mathrm{CoFe}_{2} \mathrm{O}_{4} \quad$ nanoparticles. Transactions of Nonferrous Metals Society of China, 17(5), 11181122. 